\title{
Modelling Interconnectedness of Subsurface Flow Processes from a Simple Conceptual Infiltration Model
}

\author{
T. A. Ewemoje and A. Y. Sangodoyin \\ Department of Agricultural and Environmental Engineering \\ Faculty of Technology, University of Ibadan, Ibadan, Nigeria
}

\begin{abstract}
The study determined subsurface flow processes of 92.3 ha catchment area in order to examine functional relationship among the surface and subsurface flow variables from the water balance components data. Days without rainfall had zero infiltration while peak values of infiltrated water corresponded with peak rainfall. However, the Crawford and Linsley infiltration model was deficient by its inability to distinguish between days of zero rainfall and days when rainfall was less than $1.0 \mathrm{~mm}$. Interflow occurred continuously even when there was no rainfall. This was shown to be responsible for the stream flows on dry days. Hence, total subsurface flows, a combination of interflow and groundwater flow, had the two components contributing to stream flow on days with rainfall. On days without rainfall, the interflow component was the only contributor to subsurface flows.
\end{abstract}

\section{Introduction}

An important area of research in landsurface hydrological processes stems from increasing demand on water resources throughout the world (Scanlon et al., 2007). This necessitates the study of impacts of climate (Kobayashi \& Salam, 2000; Ma et al., 2008), physical characteristics of catchments (Moon et al., 2004; Rushton et al., 2006; Cornejo et al., 2007) and human activities on hydrology and water resources management (Guo et al., 2004; Shukla \& Jaber, 2007; Elliot \& Glaza, 2007). Ma et al. (2008) reported that effects of climate change on hydrology vary from one location to another and needed to be investigated using local climate change situations.

According to Chavez et al. (2007), knowledge of surface runoff or streamflow generation is desirable for planning and management of water resources projects. In recent years, there has been an improvement in the understanding of surface and groundwater interactions among hydrologists and water resources management personnel (Callahan et al., 2004; Rushton et al., 2006). Sharma et al. (1987) emphasized the significance of infiltration in catchments hydrology. It was reported that the infiltration process determines the partitioning of precipitation into surface runoff and water available for plant growth or drainage.

Soil infiltration is considered to be a critical parameter for the building and running of hydrological and soil erosion models designed to support catchments management in tropical countries, but their development and use are hampered by theoretical and practical problems in the management of soil infiltrability. Methods aimed at predicting infiltration from soil properties, such as saturated hydraulic conductivity or sorptivity, present several shortcomings for predicting 
infiltration under rainfall (Bowyer-Bower, 1993). Infiltration is a dynamic process, both within a single rainstorm and on a seasonal basis, and such approaches only partially take into account dynamic aspects (Stone et al., 1996), as they assume constant soil properties with time.

Precipitation plays a crucial role in determining surface hydrologic processes (Guo et al., 2004) and inability of water to infiltrate into the soil or store rainfall resulted to runoff formation. Thus, according to Chavez et al. (2007), watershed characteristics such as area, average slope, vegetation cover and soil properties also influence runoff rate and volume. Runoff simulation models transform excess infiltration to runoff either using physically based models (Corradini et al., 1994), or conceptual models (Diskin \& Nazimov, 1995), or empirical relations of the Soil Conservation Service (Chahinian et al., 2005). Four widely used infiltration simulation models, as given by Chahinian et al. (2005), correspond to two physically based models of Philip and Morel-Seytoux, a Horton conceptual model and the simple Soil Conservation Service model.

All aforementioned models required rainfall intensity as input parameter, which is often unavailable in many developing countries due to limitation of instrumentation. Hence, the choice is the Crawford-Linsley model, which requires only the commonly available record of rainfall amounts in addition to physical characteristics of the watershed. No conceptual/physically based techniques may operate effectively without considering physical and hydrological characteristics of watersheds (Nejadhashemi et al., 2007).
The paper presents use of conceptual model in the conversion of rainfall to streamflow, wherein the basic processes of infiltration, interflow, and groundwater storage are separated, but their algorithms are basically calibrated input-output relationships of water balance equation of a watershed.

\section{Materials and methods}

\section{Study area}

Ona river, with catchment's area of 92.3 ha, is located at about $500 \mathrm{~m}$ of IITA meteorological station, Ibadan, at $7^{\circ} 29^{1} \mathrm{~N}$ and $3^{\circ} 54^{1} \mathrm{E}$ (Fig. 1). Eze (1997) reported that Crystalline rocks of pre-Cambrian basement complex underlie this area. Mean annual rainfall for Ibadan is around $1270 \mathrm{~mm}$ (Lal, 1993). Mean day length of this latitude is $12 \mathrm{~h}$, ranging from a minimum of $11.5 \mathrm{~h}$ in December to a maximum of $12.7 \mathrm{~h}$ in June.

\section{Infiltration model}

Infiltration model was determined using Crawford \& Linsley (1966) infiltration equation:

$$
\overline{5}_{t}=\frac{\mathrm{INF}}{\left(\mathrm{LZS}_{\mathrm{t}-1} / \mathrm{LZSN}\right)^{\mathrm{b}}} \ldots \ldots \ldots \ldots \ldots \ldots(1)
$$

where $\overline{5_{t}}=$ Segment mean infiltration capacity in $\mathrm{mm}$ at time $(\mathrm{t}), \mathrm{INF}=\mathrm{a}$ parameter representing an index infiltration level, physically related to the characteristics of catchment. Typical value ranges between $0.25-1.27 \mathrm{~mm}$, a value of $1.02 \mathrm{~mm}$ was chosen. $\mathrm{LZS}_{\mathrm{t}-1}=$ actual value of soil moisture storage at time (t-1) in the lower soil zone $(\mathrm{mm} / \mathrm{area}) . \mathrm{LZSN}=$ soil moisture storage in the lower soil zone equivalent to field capacity (mm/area). 


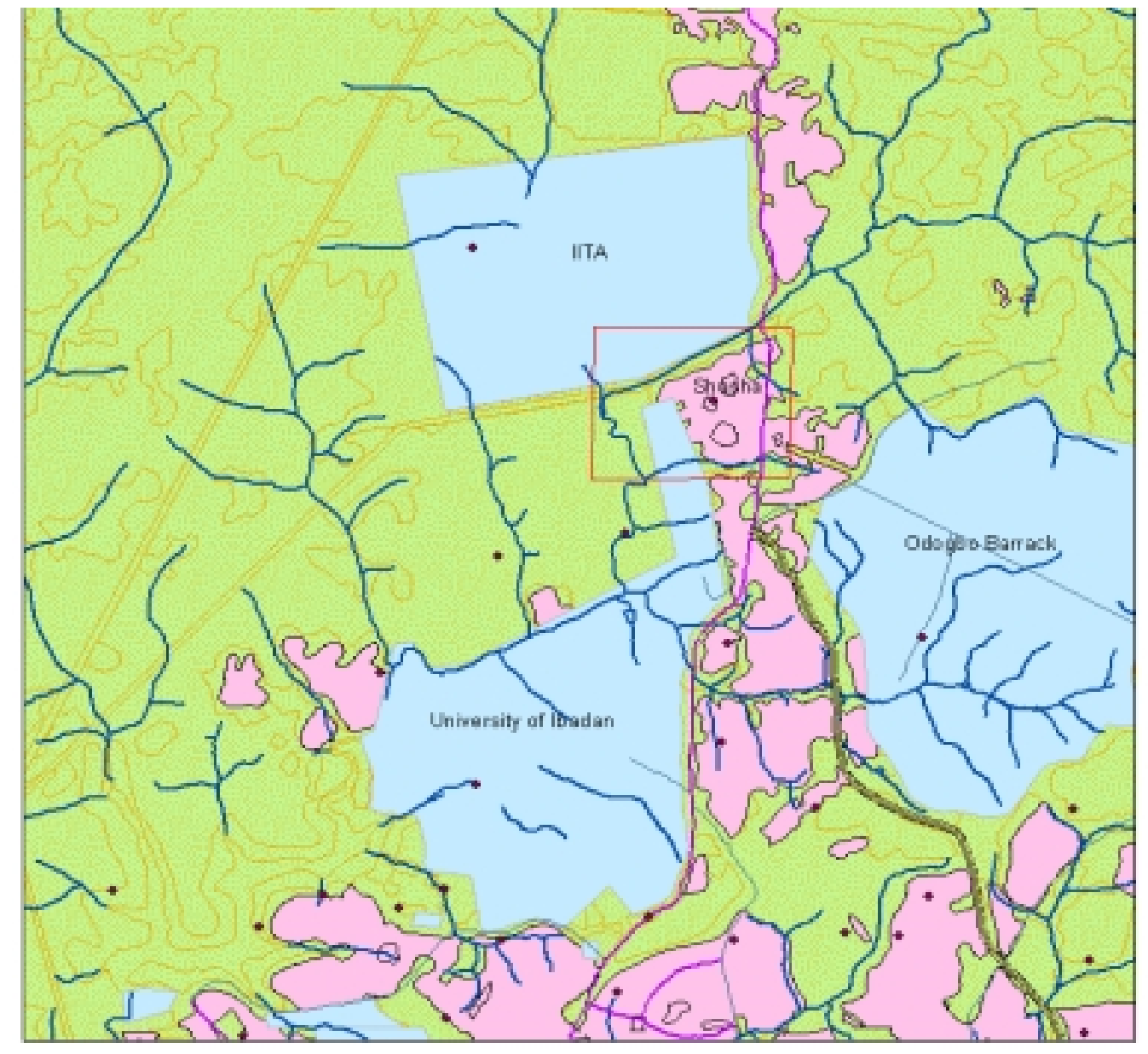

\section{Legend}

$\square$ Study Area

Roads

Express

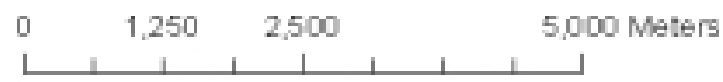

$\phi$

- City Highway

— Primary road

- Rivers

$\square$ Built Up area

Vegetation

Build up landuse

Veg95

Fig. 1. The study location map

West African Journal of Applied Ecology, vol. 16, 2009 
$\mathrm{b}=$ exponent, a value of 2 , adopted following numerous trials by Crawford \& Linsley (1966).

In the infiltration expression, both INF and LZSN are fixed parameters. To determine actual value of soil moisture storage at time $\mathrm{t}-1$ in the lower soil zone, $62 \mathrm{~mm}$ diameter soil sampling core was used. The topsoil depth at the upstream, midstream and downstream sections were 304.8, 533.4 and $457.2 \mathrm{~mm}$, respectively. Soil-sampling cans used to collect the top $300 \mathrm{~mm}$ soil samples were labelled $D_{i j}(D-$ Downstream $), M_{i j}$ $\left(\mathrm{M}\right.$ - Midstream) and $\mathrm{U}_{\mathrm{ij}}(\mathrm{U}-\mathrm{Upstream})$ for the topsoil and subsoil; where $i=1$, for topsoil and $\mathrm{i}=2$, for subsoil. $\mathrm{j}=1,2$, and 3 for the three sampling points. At each sampling point, six samples were collected (three topsoil and three subsoil section).

Samples were taken from $0-30 \mathrm{~cm}$ and depth greater than $30 \mathrm{~cm}$ of the soil profile in an airtight container for weighing on an electronic weighing balance. The soil samples were dried at $105{ }^{\circ} \mathrm{C}$ to a constant weight for $24 \mathrm{~h}$. After drying, soil and container were weighed again.

Dry weight fraction, $\mathrm{W}=$ (Wet weight -

Dry weight)/Dry weight.

To determine LZSN, particle size distribution was characterized according to the system of International Society of Soil Science.

Topsoil samples were characterized as sandy clay loam while subsoil was clay textured when the soil samples percent sand and percent clay were inputted into the National Water and Climate Center Irrigation Water Management model - 'Soil Water Characteristics' (National Resources Conservation Service; NRCS). Hence, the topsoil belongs to the NRCS soil hydrologic group A. Study location subsoil is clay with $120 \mathrm{~mm}$ soil moisture available at field capacity. The estimated LZSN value was $120 \mathrm{~mm}$.

Interflow is routed back to streams while the groundwater flow is lost to deep percolation.

$\mathrm{G}_{\mathrm{t}}=\mathrm{G}_{\mathrm{w}}+$ Interflow

where $G_{t}=$ Total subsurface runoff from land to stream and $\mathrm{G}_{\mathrm{w}}=$ Groundwater flow (all in $\mathrm{mm}$ )

To obtain total runoff from land surface, assuming change in storage $\left(\Delta \mathrm{S}_{\mathrm{t}}\right)$ to be zero;

$$
R_{t}=P_{t}-E_{t}-G_{w}-\text { Interflow }
$$

where $R_{t}=$ total runoff from land surface $(\mathrm{mm}) ; \mathrm{P}_{\mathrm{t}}=$ total precipitation over land and water surfaces $(\mathrm{mm}) ; \mathrm{E}_{\mathrm{t}}=$ total evaporation from land and water surfaces $(\mathrm{mm})$.

\section{Interflow}

Water available for interflow was based on soil moisture levels and the local infiltration rate (Fleming, 1975). Water was allocated to interflow as:

$$
\overline{5}=\overline{5}+\overline{5}(\mathrm{c}-1) \text {. }
$$

where; $5=$ total mean infiltration capacity; $\overline{5}=$ mean infiltration capacity of the area; $c$ $=\mathrm{a}$ variable.

$$
\text { Interflow }=\mathrm{C} / 2(\mathrm{LZS} / \mathrm{LZSN})
$$

\section{Groundwater storage}

A simplification of the process is to obtain a fraction of water accumulating in the lower zone from direct infiltration and percolation from upper zone. This fraction expressed in percentage was based on the functions in the following equations by (Fleming, 1975).

$$
\begin{aligned}
& \mathrm{P}_{\mathrm{g}}=100 \frac{\mathrm{LZS}}{\mathrm{LZSN}}\left(\frac{1.0}{1.0+\mathrm{Z}}\right)^{\mathrm{Z}} \text { for } \frac{\mathrm{LZS}}{\mathrm{LZSN}}<1 \\
& \left.\left.\mathrm{P}_{\mathrm{g}}=100\left[1.0-\left(\frac{1.0}{1.0+\mathrm{Z}}\right)\right]^{\mathrm{Z}} \text { for } \frac{\mathrm{LZS}}{\mathrm{LZSN}}\right)\right]>1 \ldots \text { (7) } \\
& \mathrm{Z}=1.5\left(\frac{\mathrm{LZS}}{\mathrm{LZSN}}-1.0\right)+1.0
\end{aligned}
$$


where $\mathrm{P}_{\mathrm{g}}=$ percentage of moisture entering groundwater storage.

\section{Precipitation}

Daily precipitation data were obtained from International Institute of Tropical Agriculture (IITA) automatic weather station, located about $500 \mathrm{~m}$ from Ona river.

\section{Results}

\section{Soil moisture}

Unit area of cylindrical soil sample with can radius of $6.4 \mathrm{~cm}$ was $128.68 \mathrm{~cm}^{2}$. Also, soil depth in soil sampling can is $6.1 \mathrm{~cm}$. Therefore, soil sample volume, $\mathrm{V}=128.68$ $\times 6.1=784.95 \mathrm{~cm}^{3}$

Bulk density, $\gamma=\mathrm{W} / \mathrm{V}=13.79 / 784.95=$ $0.0176 \mathrm{~g} / \mathrm{cm}^{3}$

Soil moisture $=\gamma \times \mathrm{W}=0.0176 \times 13.79=$ $0.24 \mathrm{~g} / \mathrm{cm}^{3}$

Furthermore, soil samples were taken approximately within $50.8 \mathrm{~cm}$ lower soil zone. Soil Moisture per unit area $=(0.24 \times 50.8)=$ $12.19 \mathrm{~g} / \mathrm{cm}^{2}$.

Considering topsoil and subsoil layers of the field;

Soil moisture per unit area $=2 \times 12.19=$ $24.38 \mathrm{~g} / \mathrm{cm}^{2}$. Hence, $\mathrm{LZN}_{\mathrm{t}-1}=24.4 \mathrm{~mm}$

Dry weight fraction, $\mathrm{W}=(5614.05-$ $4933.78) / 4933.78=0.1379=13.79 \%$

\section{Infiltration}

Substituting INF, LZS $_{\mathrm{t}-1}$ and LZSN in Equation 1, segment mean infiltration capacity at time $\mathrm{t}$ (daily) was computed. Rainfall in mm was plotted against percent of area with infiltration capacity less than or equal to the stated value to obtain the volume of water infiltrated. A sample of the Crawford-Linsley infiltration graph for the first 6 days in September was shown in Fig. 2 . Days without rainfall, which is the source of moisture supply, are indicated blank as observed in days $1,2,4$, and 5. On the 3rd day in September with $60.6 \mathrm{~mm}$ of moisture supply, the $37.88 \mathrm{~mm}$ infiltrated volume of water was indicated by the shaded segment. Tables 1 and 2 show the Segment mean infiltration capacity.

\section{Interflow and groundwater storage}

Substituting the values of $\overline{5}$ and $\overline{5}$ in Equation 4 gives the interflow component, C. This was substituted together with LZS and LZSN in Equation 5 to give interflow water in Table 3; resulting 5 for September and October to be $7.60 \mathrm{~mm}$ and $7.52 \mathrm{~mm}$. Segments mean infiltration capacity for September being higher than October indicated that more water infiltrated from moisture received in September than October. Hence, more water was available for interflow and groundwater storage in September than October.

Values were substituted in Equations 25 and results of groundwater storages were presented in Tables 4 and 5, respectively. As previously observed for interflow, volume of water available for groundwater storage was more in September than October.

\section{Runoff}

Values of total runoff from land surface were computed using the water balance equation 3. Simulated runoff of study location is presented in Tables 6 and 7.

\section{Discussion}

Infiltration and precipitation analysis On days without precipitation, zero volume of water infiltrated. Furthermore, the Crawford-Linsley model computes zero infiltration on days in which precipitation is less than $1.0 \mathrm{~mm}$. Peak values of infiltrated 


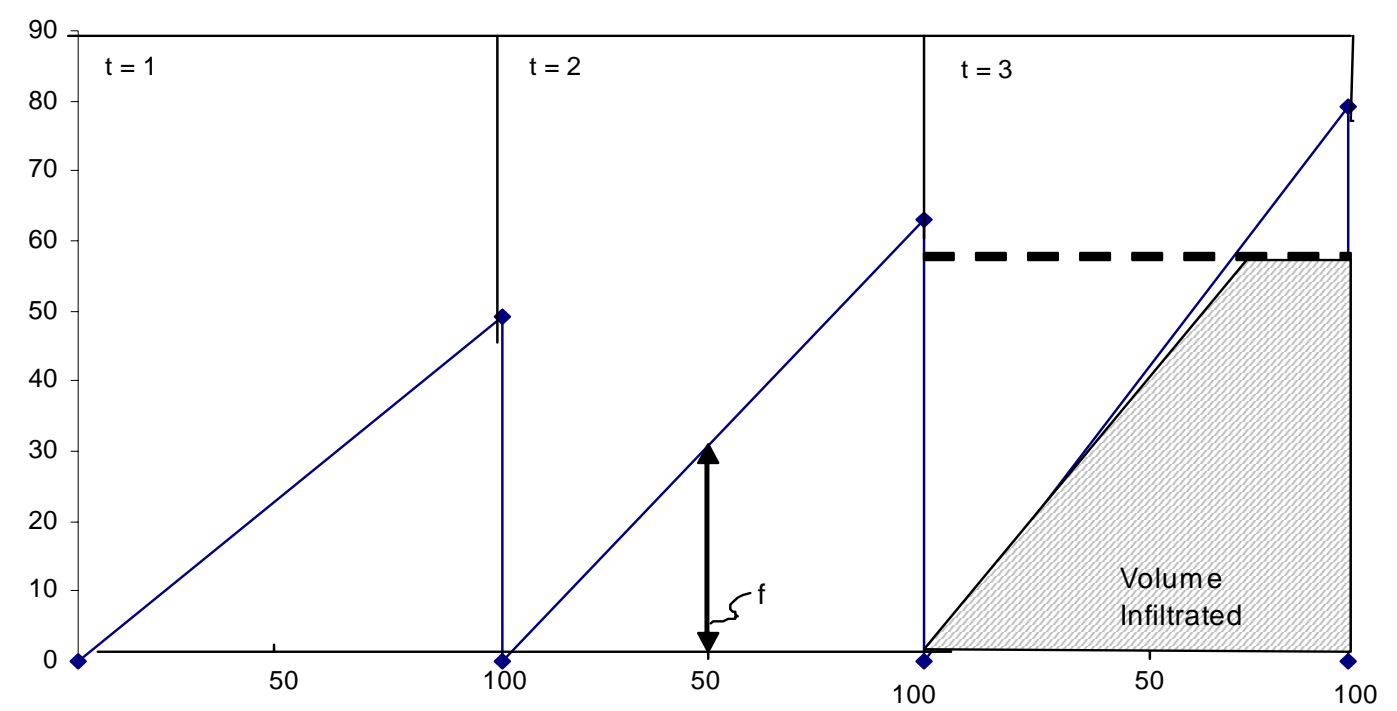

Percent of area with infiltration capacity less than or equal to stated value

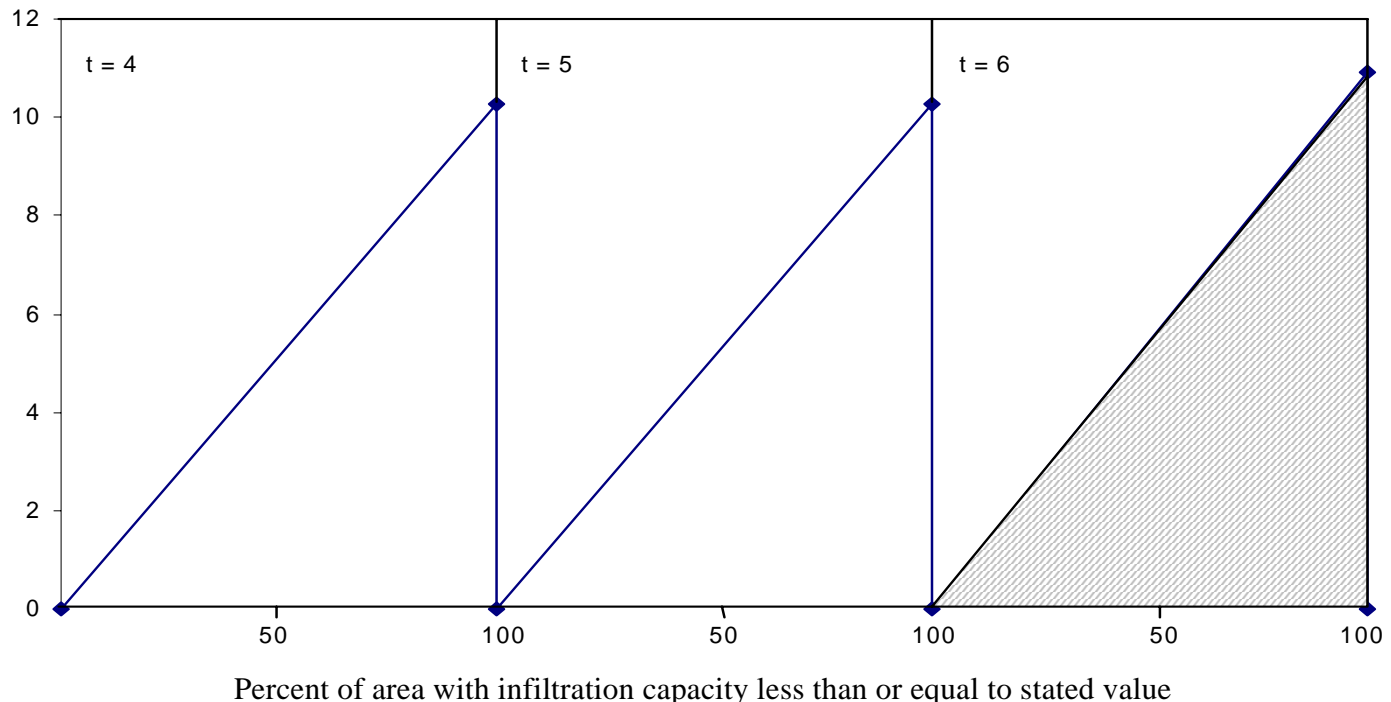

Fig. 2. Crawford and Linsley graph (Sept 1-6) 


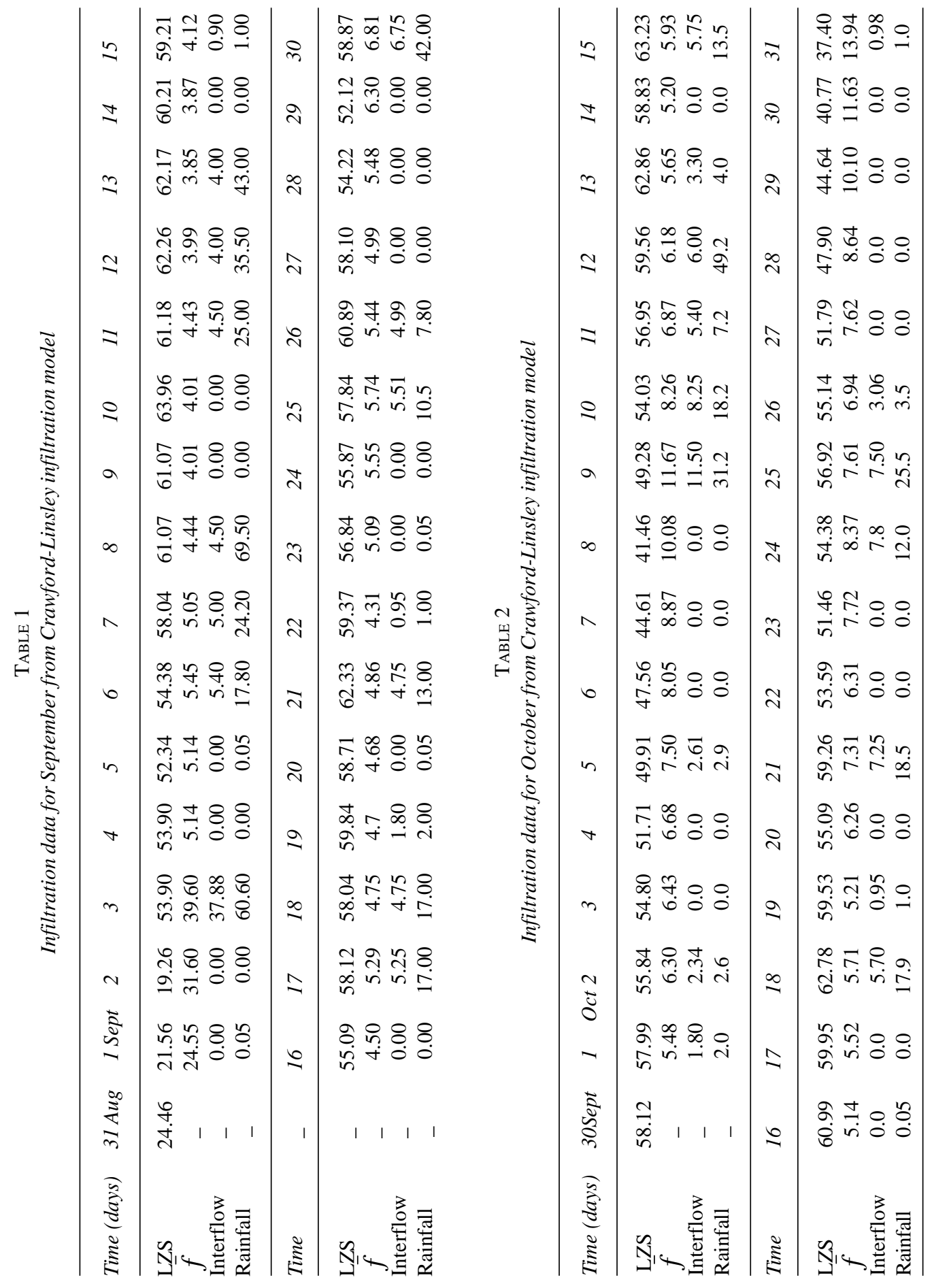

West African Journal of Applied Ecology, vol. 16, 2009 
TABLE 3

Interflow component from Crawford-Linsley model

\begin{tabular}{|c|c|c|c|c|}
\hline \multirow[t]{2}{*}{ Day } & \multicolumn{2}{|c|}{ September } & \multicolumn{2}{|c|}{ October } \\
\hline & $C$ & Interflow $(\mathrm{mm})$ & $C$ & Interflow $(\mathrm{mm})$ \\
\hline 1 & 0.31 & 0.27 & 1.37 & 1.02 \\
\hline 2 & 0.24 & 0.21 & 1.19 & 0.89 \\
\hline 3 & 0.19 & 0.17 & 1.17 & 0.89 \\
\hline 4 & 1.48 & 1.09 & 1.13 & 0.86 \\
\hline 5 & 1.48 & 1.09 & 1.00 & 0.78 \\
\hline 6 & 1.39 & 0.13 & 0.98 & 0.73 \\
\hline 7 & 1.50 & 1.10 & 0.85 & 0.67 \\
\hline 8 & 1.71 & 1.23 & 0.75 & 0.60 \\
\hline 9 & 1.90 & 1.34 & 0.64 & 0.52 \\
\hline 10 & 1.90 & 1.34 & 0.91 & 0.71 \\
\hline 11 & 1.72 & 1.23 & 1.09 & 0.83 \\
\hline 12 & 1.90 & 1.34 & 1.22 & 0.92 \\
\hline 13 & 1.97 & 1.38 & 1.33 & 0.99 \\
\hline 14 & 1.96 & 1.38 & 1.45 & 1.06 \\
\hline 15 & 1.84 & 1.31 & 1.27 & 0.95 \\
\hline 16 & 1.66 & 1.20 & 1.46 & 1.07 \\
\hline 17 & 1.44 & 1.06 & 1.36 & 1.01 \\
\hline 18 & 1.60 & 1.016 & 1.32 & 0.98 \\
\hline 19 & 1.59 & 1.16 & 1.44 & 1.06 \\
\hline 20 & 1.62 & 1.17 & 1.20 & 0.91 \\
\hline 21 & 1.56 & 1.14 & 1.03 & 0.79 \\
\hline 22 & 1.76 & 1.26 & 1.19 & 0.90 \\
\hline 23 & 1.49 & 1.09 & 0.97 & 0.76 \\
\hline 24 & 1.37 & 1.02 & 0.90 & 0.71 \\
\hline 25 & 1.32 & 0.99 & 0.99 & 0.77 \\
\hline 26 & 1.40 & 1.03 & 1.08 & 0.83 \\
\hline 27 & 1.52 & 1.11 & 0.99 & 0.77 \\
\hline 28 & 1.39 & 1.03 & 0.87 & 0.69 \\
\hline 29 & 1.21 & 0.91 & 0.74 & 0.60 \\
\hline 30 & 1.12 & 0.85 & 0.65 & 0.53 \\
\hline 31 & & & 0.54 & 0.45 \\
\hline
\end{tabular}


TABLE 4

Groundwater storage in September

\begin{tabular}{lccccc}
\hline Days & LZS/LZSN & $Z$ & $P_{(g)}(\%)$ & $I_{(\mathrm{mm})}$ & $G_{w}$ Storage $(\mathrm{mm})$ \\
\hline 3 & 0.1605 & -0.2593 & 14.85 & 37.88 & 5.62 \\
6 & 0.4325 & 0.1487 & 42.37 & 5.40 & 2.29 \\
7 & 0.4493 & 0.1740 & 43.69 & 5.00 & 2.18 \\
8 & 0.4796 & 0.2193 & 45.92 & 4.50 & 2.07 \\
11 & 0.4798 & 0.2197 & 45.93 & 4.50 & 2.07 \\
12 & 0.5055 & 0.2582 & 47.64 & 4.00 & 1.91 \\
13 & 0.5144 & 0.2716 & 48.19 & 4.00 & 1.93 \\
15 & 0.4975 & 0.2462 & 47.13 & 0.90 & 0.42 \\
17 & 0.4391 & 0.1586 & 42.90 & 5.25 & 2.25 \\
18 & 0.4632 & 0.1948 & 44.74 & 4.75 & 2.13 \\
19 & 0.4626 & 0.1939 & 44.70 & 1.80 & 0.80 \\
21 & 0.4583 & 0.1874 & 44.38 & 4.75 & 2.11 \\
22 & 0.4865 & 0.2298 & 46.39 & 0.95 & 0.44 \\
25 & 0.4214 & 0.1321 & 41.45 & 5.51 & 2.00 \\
26 & 0.4329 & 0.1494 & 42.40 & 4.99 & 2.00 \\
30 & 0.3869 & 0.0804 & 38.45 & 6.75 & 2.00 \\
\hline
\end{tabular}

TABLE 5

Groundwater storage in October

\begin{tabular}{llllll}
\hline Days & LZS/LZSN & $Z$ & $P_{(g)}(\%)$ & $I_{(\mathrm{mm})}$ & $G_{w}$ Storage $(\mathrm{mm})$ \\
\hline 1 & 0.4314 & 0.1472 & 42.28 & 1.80 & 0.76 \\
2 & 0.4209 & 0.1314 & 41.41 & 2.34 & 0.97 \\
5 & 0.3688 & 0.0531 & 36.78 & 2.61 & 0.96 \\
9 & 0.2957 & -0.0565 & 29.47 & 11.50 & 3.39 \\
10 & 0.3514 & 0.0271 & 35.11 & 8.25 & 2.90 \\
11 & 0.3853 & 0.0779 & 38.31 & 5.40 & 2.07 \\
12 & 0.4061 & 0.1092 & 40.15 & 6.00 & 2.41 \\
13 & 0.4247 & 0.1371 & 41.73 & 3.30 & 1.38 \\
15 & 0.4146 & 0.1219 & 40.88 & 5.75 & 2.35 \\
18 & 0.4225 & 0.1337 & 41.55 & 5.70 & 2.37 \\
19 & 0.4424 & 0.1636 & 43.16 & 0.95 & 0.41 \\
21 & 0.3737 & 0.0605 & 37.24 & 7.25 & 2.70 \\
24 & 0.3490 & 0.0236 & 34.88 & 7.80 & 2.72 \\
25 & 0.3661 & 0.0492 & 36.52 & 7.50 & 2.74 \\
26 & 0.3832 & 0.0749 & 38.11 & 3.06 & 1.17 \\
31 & 0.2705 & -0.0943 & 26.80 & 0.98 & 0.26 \\
\hline
\end{tabular}

West African Journal of Applied Ecology, vol. 16, 2009 
TABLE 6

Water balance for September

\begin{tabular}{|c|c|c|c|c|c|c|}
\hline Days & Pt $(\mathrm{mm})$ & $E t(m m)$ & Inter $(\mathrm{mm})$ & $G w(m m)$ & $G t(\mathrm{~mm})$ & $R t(m m)$ \\
\hline 1 & 0.05 & 3.8 & 0.27 & 0 & 0.27 & -4.02 \\
\hline 2 & 0 & 3.4 & 0.21 & 0 & 0.21 & -3.61 \\
\hline 3 & 60.6 & 2.76 & 0.17 & 5.62 & 5.79 & 52.05 \\
\hline 4 & 0 & 3.95 & 1.09 & 0 & 1.09 & -5.04 \\
\hline 5 & 0.05 & 2.64 & 1.09 & 0 & 1.09 & -3.68 \\
\hline 6 & 17.8 & 2.35 & 1.03 & 2.29 & 3.32 & 12.13 \\
\hline 7 & 24.2 & 2.2 & 1.1 & 2.18 & 3.28 & 18.72 \\
\hline 8 & 69.5 & 2.74 & 1.23 & 2.07 & 3.3 & 63.46 \\
\hline 9 & 0 & 4.01 & 1.34 & 0 & 1.34 & -5.35 \\
\hline 10 & 0 & 2.63 & 1.34 & 0 & 1.34 & -3.97 \\
\hline 11 & 25 & 3.5 & 1.23 & 2.07 & 3.3 & 18.2 \\
\hline 12 & 35.5 & 2.7 & 1.34 & 1.91 & 3.25 & 29.55 \\
\hline 13 & 43 & 2.46 & 1.38 & 1.93 & 3.31 & 37.23 \\
\hline 14 & 0.05 & 3.09 & 1.38 & 0 & 1.38 & -4.42 \\
\hline 15 & 1 & 3.54 & 1.31 & 0.42 & 1.73 & -4.27 \\
\hline 16 & 0 & 3.77 & 1.2 & 0 & 1.2 & -4.97 \\
\hline 17 & 17 & 3.78 & 1.06 & 2.25 & 3.31 & 9.91 \\
\hline 18 & 17 & 3.73 & 1.16 & 2.13 & 3.29 & 9.98 \\
\hline 19 & 2 & 2.98 & 1.16 & 0.8 & 1.96 & -2.94 \\
\hline 20 & 0.05 & 2.77 & 1.17 & 0 & 1.17 & -3.89 \\
\hline 21 & 13 & 3.79 & 1.14 & 2.11 & 3.25 & 5.96 \\
\hline 22 & 1 & 2.55 & 1.26 & 0.44 & 1.7 & -3.25 \\
\hline 23 & 0.05 & 1.97 & 1.09 & 0 & 1.09 & -3.01 \\
\hline 24 & 0 & 3.61 & 1.02 & 0 & 1.02 & -4.63 \\
\hline 25 & 10.5 & 3.21 & 0.99 & 2.28 & 3.27 & 4.02 \\
\hline 26 & 7.8 & 3.72 & 1.03 & 2.12 & 3.15 & 0.93 \\
\hline 27 & 0 & 3.79 & 1.11 & 0 & 1.11 & -4.9 \\
\hline 28 & 0 & 4.03 & 1.03 & 0 & 1.03 & -5.06 \\
\hline 29 & 0 & 4.26 & 0.91 & 0 & 0.91 & -5.17 \\
\hline 30 & 42 & 2.92 & 0.85 & 2.6 & 3.45 & 35.63 \\
\hline$\Sigma$ & & & 31.69 & & & 225.59 \\
\hline
\end{tabular}


TABLE 7

Water balance for October

\begin{tabular}{|c|c|c|c|c|c|c|}
\hline Days & $P t(\mathrm{~mm})$ & $E t(m m)$ & Inter $(\mathrm{mm})$ & $G w(m m)$ & $G t(m m)$ & $R t(\mathrm{~mm})$ \\
\hline 1 & 2 & 4.21 & 1.02 & 0.76 & 1.78 & -3.99 \\
\hline 2 & 2.6 & 3.2 & 0.89 & 0.97 & 1.86 & -2.46 \\
\hline 3 & 0 & 4.07 & 0.89 & 0 & 0.89 & -4.96 \\
\hline 4 & 0 & 4.45 & 0.86 & 0 & 0.86 & -5.31 \\
\hline 5 & 2.9 & 3.54 & 0.78 & 0.96 & 1.74 & -2.38 \\
\hline 6 & 0 & 4.29 & 0.73 & 0 & 0.73 & -5.02 \\
\hline 7 & 0 & 4.1 & 0.67 & 0 & 0.67 & -4.77 \\
\hline 8 & 0 & 3.48 & 0.6 & 0 & 0.6 & -4.08 \\
\hline 9 & 31.2 & 3.94 & 0.52 & 3.39 & 3.91 & 23.35 \\
\hline 10 & 18.2 & 3.5 & 0.71 & 2.9 & 3.61 & 11.09 \\
\hline 11 & 7.2 & 3.84 & 0.83 & 2.07 & 2.9 & 0.46 \\
\hline 12 & 49.2 & 2.94 & 0.92 & 2.41 & 3.33 & 42.93 \\
\hline 13 & 4 & 4.85 & 0.99 & 1.38 & 2.37 & -3.22 \\
\hline 14 & 0 & 2.49 & 1.06 & 0 & 1.06 & -3.55 \\
\hline 15 & 13.5 & 3.96 & 0.95 & 2.35 & 3.3 & 6.24 \\
\hline 16 & 0.05 & 2.3 & 1.07 & 0 & 1.07 & -3.32 \\
\hline 17 & 0 & 2.82 & 1.01 & 0 & 1.01 & -3.83 \\
\hline 18 & 17.9 & 4.96 & 0.98 & 2.37 & 3.35 & 9.59 \\
\hline 19 & 1 & 4.79 & 1.06 & 0.41 & 1.47 & -5.26 \\
\hline 20 & 0 & 3.87 & 0.91 & 0 & 0.91 & -4.78 \\
\hline 21 & 18.5 & 4.13 & 0.79 & 2.7 & 3.49 & 10.88 \\
\hline 22 & 0 & 4.5 & 0.9 & 0 & 0.9 & -5.4 \\
\hline 23 & 0 & 4.59 & 0.76 & 0 & 0.76 & -5.35 \\
\hline 24 & 12 & 4.28 & 0.71 & 2.72 & 3.43 & 4.29 \\
\hline 25 & 25.5 & 4.47 & 0.77 & 2.74 & 3.51 & 17.52 \\
\hline 26 & 3.5 & 3.84 & 0.83 & 1.17 & 2 & -2.34 \\
\hline 27 & 0 & 4.75 & 0.77 & 0 & 0.77 & -5.52 \\
\hline 28 & 0 & 4.34 & 0.69 & 0 & 0.69 & -5.03 \\
\hline 29 & 0 & 4.58 & 0.6 & 0 & 0.6 & -5.18 \\
\hline 30 & 0 & 4.01 & 0.53 & 0 & 0.53 & -4.54 \\
\hline 31 & 1 & 3.81 & 0.45 & 0.26 & 0.71 & -3.52 \\
\hline$\Sigma$ & & & 25.25 & & & 32.54 \\
\hline
\end{tabular}

West African Journal of Applied Ecology, vol. 16, 2009 
water correspond with peak precipitation events, while the model was unable to distinguish between days of zero precipitation and days with precipitation less than $1.0 \mathrm{~mm}$.

The actual soil moisture storage, $L Z S$, is continuously changing due to losses such as evapotranspiration, deep percolation (assumed negligible due to the clayey nature of the subsoil of the study area and crystalline rocks of the pre-Cambrian basement complex, which underlie this area) and gains in direct infiltration. The time step for the simulation is daily, with the shaded segment (Fig. 2), indicating the volume of water infiltrated, and $50 \%$ of the area with infiltration capacity less than or equal to the stated value corresponds to the segment mean infiltration capacity, while $100 \%$ of the area with infiltration capacity less than or equal to the stated value corresponds to the saturated (final) infiltration capacity. The infiltration capacity is a mean for the catchment area because not all the elements of the catchment surface will be able to absorb water at the same rate due to variability in the infiltration capacity of finite elements over the catchment surface.

Comparing infiltrated depth of water using the Crawford-Linsley model, with depth of water precipitated over the location of study, stochastic (randomness) nature of precipitation was clearly evident, as one precipitation event does not depend on previous and/or next precipitation event. For the given moisture supply in Fig. 3 and 4, increased soil moisture storage tends to reduce infiltration capacity. Hence, successive precipitation events resulted in decrease in depth of water infiltrated as a result of the soil at or near its field capacity.
A break of 2-3 days before rainfall events resulted in increased depth of water infiltrated. High values of infiltration recorded with first rainfall event as shown in Fig. 3 may be attributed to the observed August break. Assuming all other factors remain constant, increases in soil moisture storage tend to reduce the infiltration capacity.

\section{Interflow and groundwater storage}

The magnitude of water reaching Ona stream in September and October are 31.69 $\mathrm{mm}$ and $25.25 \mathrm{~mm}$. Interflow occurs continuously even when there are 3-4 days of no precipitation. This component of the water balance equation is shown to be responsible for stream flows on dry days. From Tables 6 and 7, moisture entering groundwater storage and surface runoff from land will only occur on days when there is substantial precipitation. Hence, total subsurface runoff (a combination of interflow and groundwater flow) will contribute to stream flow on days with precipitation, while days without precipitation will only have the interflow component contributing to subsurface runoff.

The interflow, when compared to the groundwater storage, is relatively constant. It does not vary considerably with either an increase or decrease in groundwater storage. The slight increase in interflow is noticeable after $24 \mathrm{~h}$ of a precipitation event. For instance, the $60.6 \mathrm{~mm}$ of precipitation recorded on the 3rd of September does not translate to interflow immediately on the same day. The effect was noticed on the 4 5 th of September where no precipitation event occurred. From a plot of the 


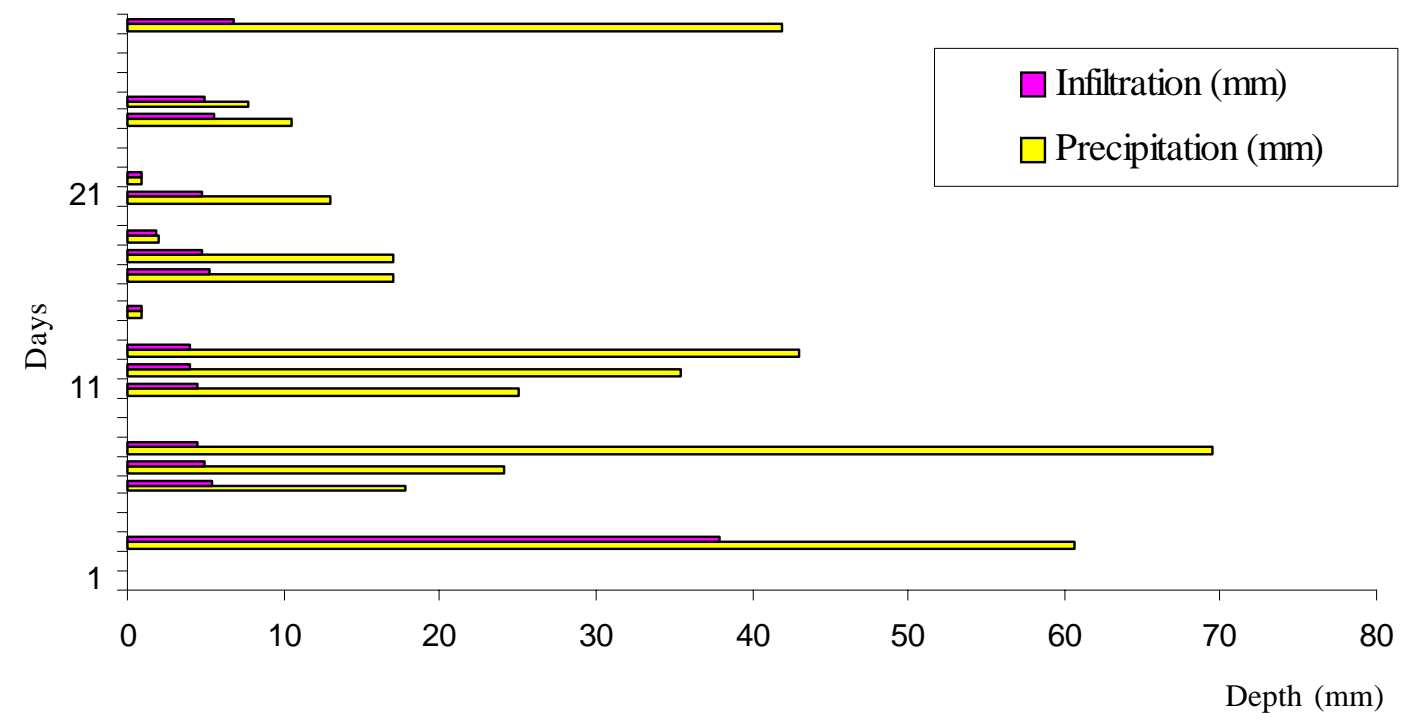

Fig. 3. Comparison of precipitation with infiltration in September

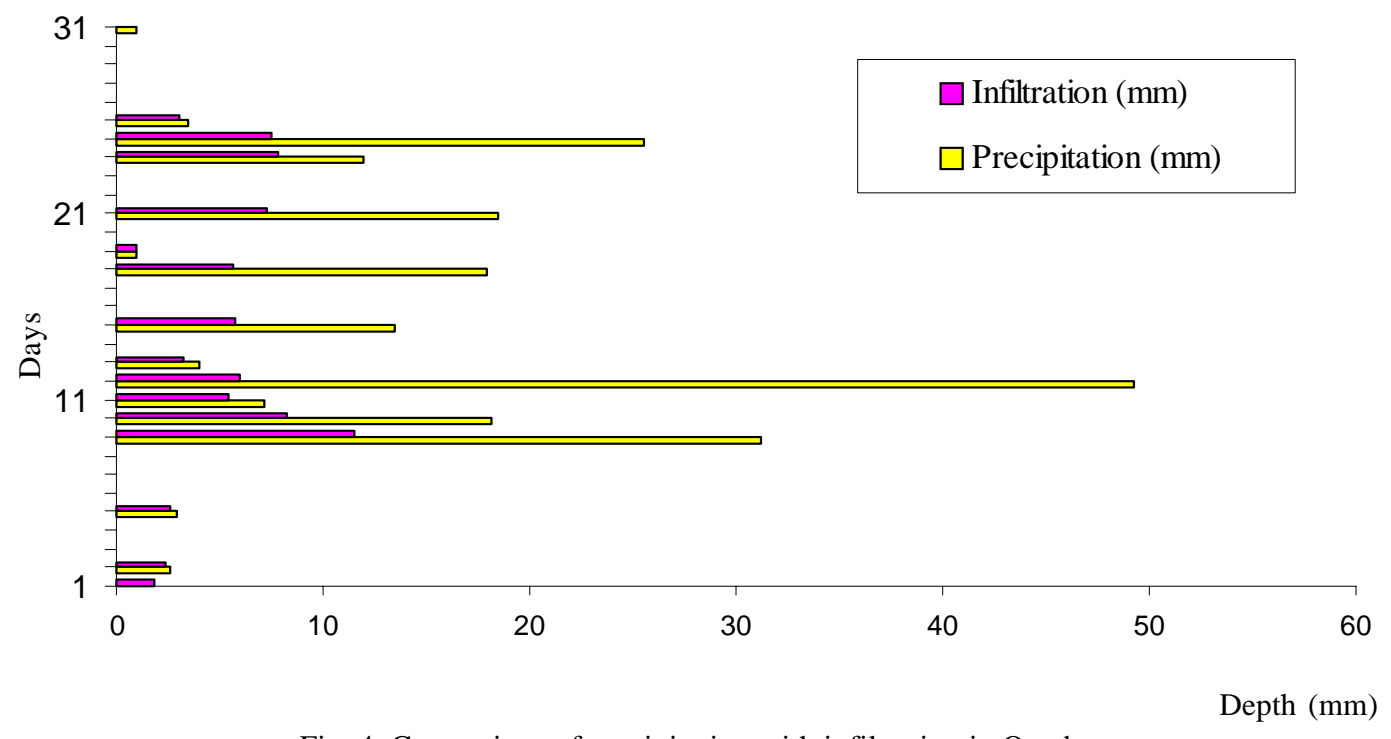

Fig. 4. Comparison of precipitation with infiltration in October 
groundwater discharge in September and October (Fig. 5 and 6), the long-term flow or base flow, an indication of discharge of groundwater, can be attributed to the interflow component. Thus, interflow can still contribute to stream flow even for 3-4 days of no precipitation in study location.

From the water balance of the study location (Tables 6 and 7), volume of water entering groundwater storage is dependent on the antecedent (previous) soil moisture condition. Peak precipitation event does not necessarily correspond to peak groundwater storage as the $25.0 \mathrm{~mm}$ and $35.5 \mathrm{~mm}$ of recorded precipitation correspond to 2.07 $\mathrm{mm}$ and $1.91 \mathrm{~mm}$ of groundwater storage. The reduction in groundwater storage after 1-2 days of consecutive precipitation events may be attributed to the soil being at or near its field capacity; hence, there is reduction in voids for the next precipitation event. Similar situation was observed from 9th to 12th October (Table 7). The relationship between moisture supply (precipitation) and

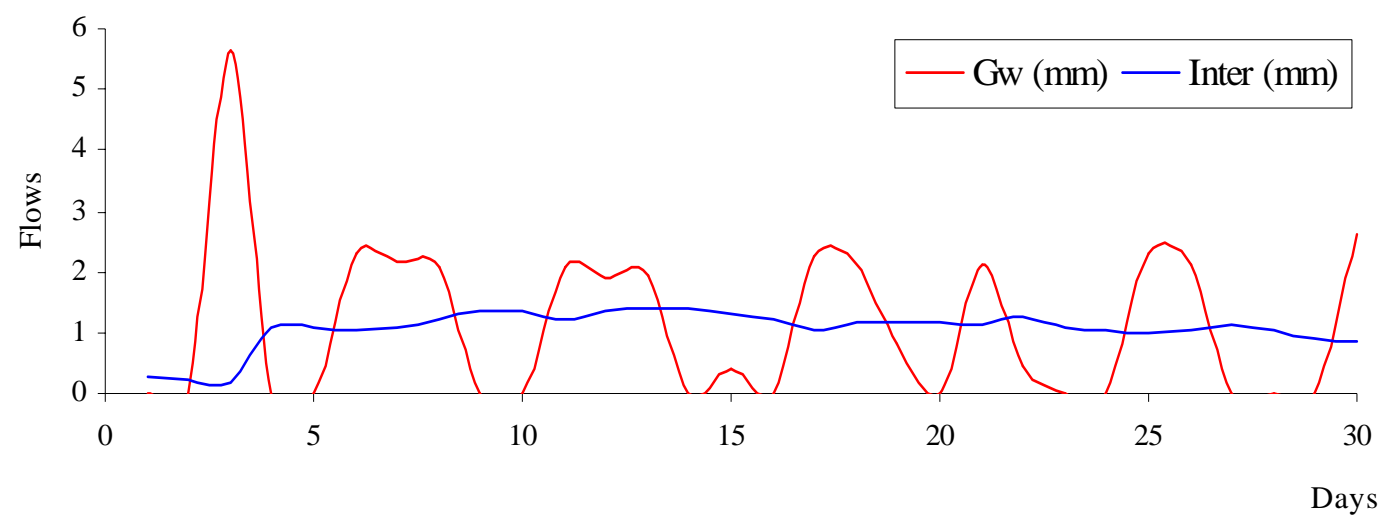

Fig. 5. Groundwater and interflow variation in September

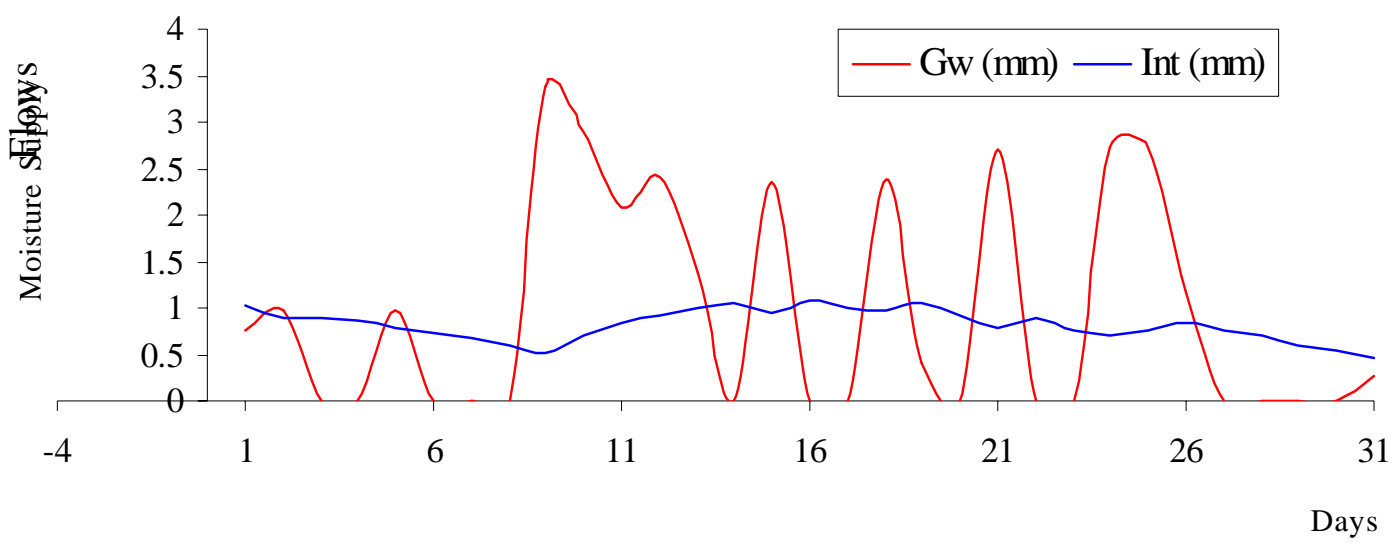

Fig. 6. Groundwater and interflow variation in October 
groundwater storage (Fig. 7 and 8) shows that storage will be zero when there is no precipitation.

\section{Conclusion}

Determining water contributing to stream flow from surface and subsurface runoff gives volume of water that can be abstracted without creating acute water shortage problems for dependent lives downstream section in vulnerable seasons. From the water balance components, days without rainfall were shown to have zero infiltration, while peak values of infiltrated water correspond with peak rainfall. However, the model was deficient by its inability to distinguish between days of zero rainfall and days when rainfall is less than $1.0 \mathrm{~mm}$.

Interflow occurred continuously even when there was no rainfall. This was shown

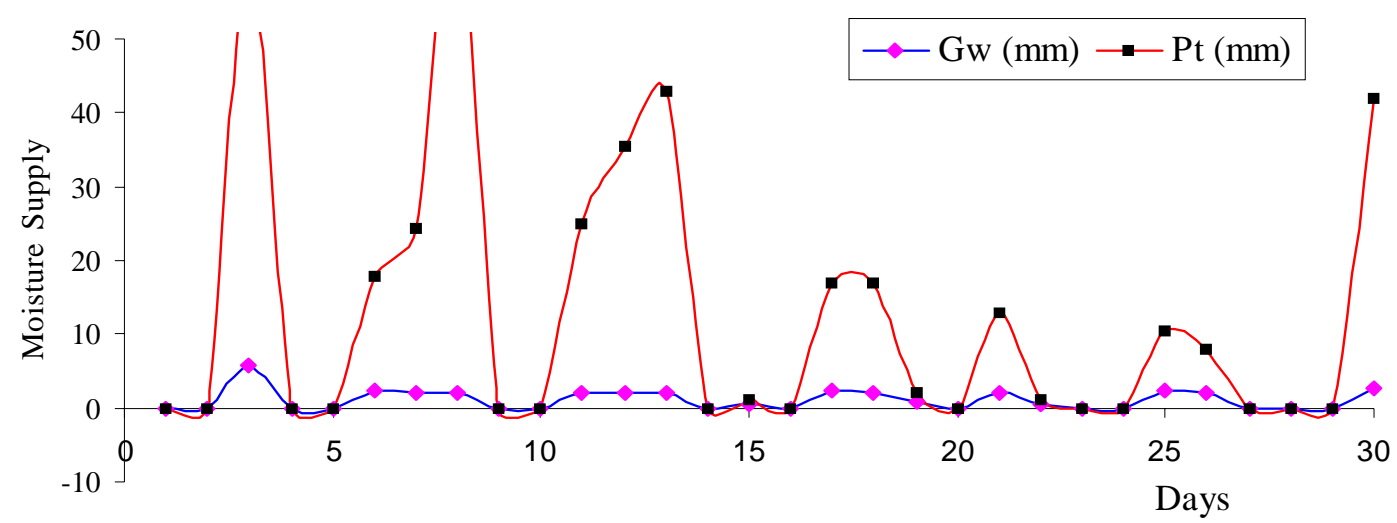

Fig. 7. Precipitation and groundwater storage relationship in September

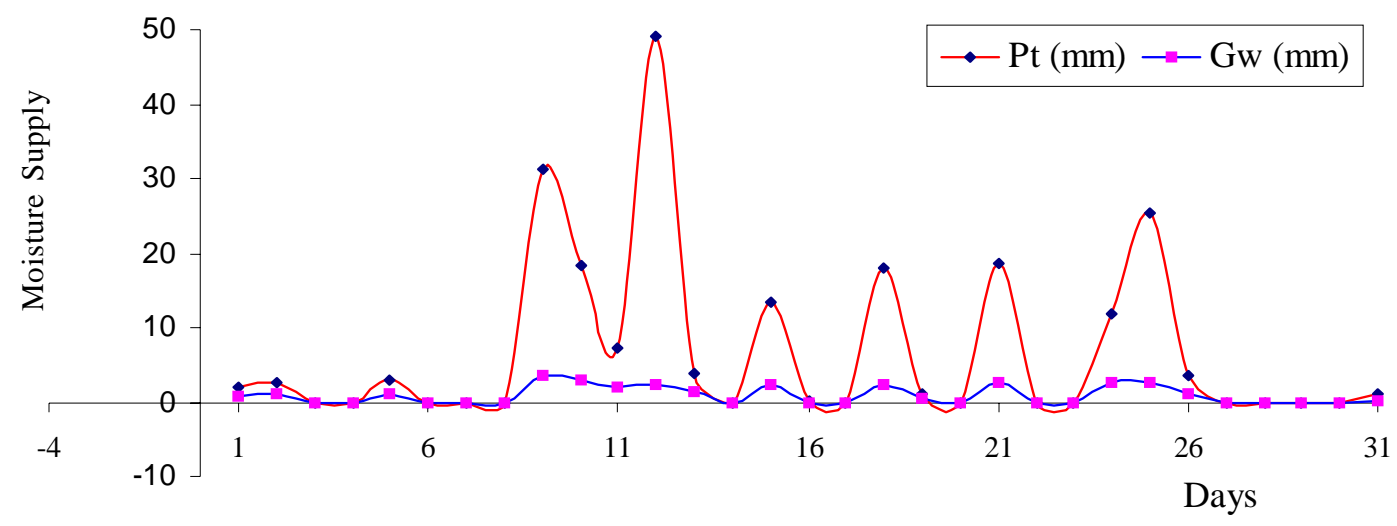

Fig. 8 Precipitation and groundwater storage relationship in Octobert

West African Journal of Applied Ecology, vol. 16, 2009 
to be responsible for the stream flows on dry days. Hence, a combination of interflow and groundwater flow will have the two components contributing to stream flow on days with rainfall. On days without rainfall, interflow component will be the only contributor to subsurface runoff. This is usually applicable to ephemeral streams which always have flows during the wet season while flows will cease during the dry season.

Daily time step used in the water balance model development could be reduced to hourly time step in order to ascertain the effect of time step on the accuracy of modelling processes, which took the physical relevance of study area into account in the development of the process parameters, thereby, classifying the developed models as conceptual grey-box model.

\section{References}

Bowyer-Bower T. A. S. (1993). Effects of Rainfall Intensity and Antecedent Moisture on the Steadystate Infiltration Rate in Semi-arid Region. Soil Use Mgmt 9: 69-76.

Callahan T. J., Cook J. D., Coleman M. D., Amatya D. M. and Trettin C. C. (2004). Modeling Storm Water Runoff and Soil Interflow in a Managed Forest, Upper Coastal Plain of the Southwest US. ASAE/CSAE Paper No. 042254. ASAE, St. Joseph, Mich.

Chahinian N., Moussa R., Andrieux P. and Voltz M. (2005). Comparison of Infiltration Models to Simulate Flood Events at the Field Scale. J. Hydrol. 306: 191-214.

Chavez J. L., Gowda P. H., Griffin R., Rivera S. and Neale C. M. U. (2007). A Simple Empirical Stream Flow Prediction Model for Ungauged Watersheds. ASABE Paper No. 072003. ASABE, St. Joseph, Mich.

Cornejo C., Mylavarapu R. and Acharya S. (2007). Modeling of Water Subsurface Lateral Movement on Top of a Shallow Hardpan. ASABE Paper No. 072004. ASABE, St. Joseph, Mich.
Corradini C., Melone F. and Smith,R. (1994). Modelling Infiltration during Complex Rainfall Sequences. Wat. Resour. Res. 30(10): 2777-2784.

Crawford N. H. and Lansley, R. K. (1966). Digital Simulation on Hydrology: Standford Watershed Model IV. Civil Engineering Technical Report No. 39. Standford University, Palo Alto, CA.

Diskin M. and Nazimov N. (1995). Linear Reservoir with Feedback Regulated Inlet as a Model for the Infiltration Process. J. Hydrol. 172: 313-330.

Eze B. E. (1997) Rain Splash Detachment on Different Land Use Surface in a Humid Tropical Environment: A Case Study of Ibadan. (PhD Thesis.) Department of Geography, University of Ibadan, Ibadan, Nigeria.

Elliot W. J. and Glaza B. D. (2007). Variability in Runoff and Erosion from Small Forest Watersheds. ASABE Paper No. 072224. ASABE, St. Joseph, Mich.

Fleming G. (1975). Computer Simulation Techniques in Hydrology. American Elsevier Publishing Co. Inc., New York.

Guo J., Liang X. and Leung L. R. (2004). Impacts of Different Precipitation Data Sources on Water Budgets. J. Hydrol. 298: 311-334.

Kobayashi K. and Salam M. U. (2000). Comparing Simulated and Measured Values Using Mean Squared Deviation and its Components. Agron. J. 92: 345-352.

Lal R. (1993). Tillage Effects on Soil Degradation, Soil Degradation, Soil Resilience, Soil Quality, and Sustainability. Soil Tillage Res. 27: 1-8.

Ma Z., Kang S., Zhang L., Tong L. and Su X. (2008). Analysis of Impacts of Climate Variability and Human Activity on Streamflow for a River Basin in Arid Region of Northwest China. J. Hydrol. (Accepted) DOI:10.1016/j.jhydrol.2007.12.022.

Moon S. K., Woo N. K. and Lee K. S. (2004). Statistical Analysis of Hydrographs and Water-table Fluctuation to Estimate Groundwater Recharge. $J$. Hydrol. 292: 198-209.

Nejadhashemi A. P., Shirmohammadi A., Montas H. J., Sheridan J. M. and Bosch D. D. (2007). Analysis of Watershed Physical and Hydrological Effects on Baseflow Separation. ASABE Paper No. 072025. ASABE, St. Joseph, Mich.

Rushton K. R., Eilers V. H. M. and Carter R. C. (2006). Improved Soil Moisture Balance Meth- 
odology for Recharge Estimation. J. Hydrol. 318: 379-399.

Scanlon B. R., Jolly I., Sophocleous M. and Zhang L. (2007). Global Impacts of Conversion from Natural to Agricultural Ecosystem on Water Resourses: Quantity versus Quality. Wat. Resour. Res. 43: W03437, DOI:10.1029/2006WR005486.

Sharma M. L., Barron R. J. W. and Fernie M. S. (1987). Arial Distribution of Infiltration Parameters and Some Soil Physical Properties in Later- itic Catchment. J. Hydrol. 94: 109-127.

Shukla S. and Jaber F. (2007). Estimation of Groundwater Recharge in South Florida Using Drainage Lysimeters. ASABE Paper No. 072036. ASABE, St. Joseph, Mich.

Stone J., Renard K. J. and Lane L. J. (1996). Runoff Estimation on Agricultural Fields. In Soil Erosion, Conservation and Rehabilitation (M. Agassi, ed. ), pp. 203-238. Marcel Dekker Inc. New York. 